\title{
КЛІНІЧНА ОФТАЛЬМОЛОГІЯ
}

\author{
І. В. Галінська \\ Вінницький національний медичний університет імені М. І. Пирогова МОЗ України \\ - м. Вінниця, Україна
}

\section{ДО ПИТАННЯ ЕТІОЛОГІЇ ТА ЧАСТОТИ АТРОФІЇ ЗОРОВОГО НЕРВА СУДИННОГО ГЕНЕЗУ}

\begin{abstract}
Захворювання зорового нерва є основною причиною слабозорості та сліпоти. За даними літератури, серед етіологічних факторів атрофії зорового нерва (АЗН), не пов'язаних із захворюваннями центральної нервової системи (ЦНС), на першому місці знаходиться судинний чинник. У структурі причин атрофії зорового нерва судинного генезу перше місце займає передня ішемічна оптична нейропатія (ПІОН). Метою дослідження було провести аналіз етіології і частоти атрофії зорового нерва судинного генезу. Під нашим спостереженням знаходилося 38 пацієнтів (38 очей) з передньою ішемічною оптичною нейропатією. Чоловіків було 15 (39,5\%), жінок - 23 (60,5\%) особи. Вік пацієнтів склав 27-84 роки (в середньому 61,6 року). Основними етіологічними факторами ПІОН є загальна судинна патологія організму та судинна патологія зорового нерва. Частота розвитку АЗН у віддаленому періоді (1-4 роки) після перенесеної ПІОН складає $100 \%$.
\end{abstract}

Ключові слова: судинні порушення, передня ішемічна оптична нейропатія, атрофія зорового нерва.

Захворювання зорового нерва $є$ основною причиною слабозорості та сліпоти, тому вивчення цієї проблеми $€$ важливим питанням у клінічній та соціальній офтальмології [3, 4]. За даними літератури, передня ішемічна оптична нейропатія (ПIОН) у структурі причин атрофії зорового нерва судинного генезу займає перше місце і складає $41,6-49,5 \%$ серед різних його захворювань та 30-40\% від усіх форм ішемічного ураження очного яблука $[5,6,10-12]$.

На даний час розповсюдження атрофії зорового нерва (АЗН) як тяжкого ускладнення багатьох захворювань і патологічних процесів зорового аналізатора не зменшується, досягаючи в середньому по Україні 103,1 випадку на 100000 осіб [7]. Серед причин АЗН, не пов'язаних із захворюваннями ЦНС, на першому місці знаходиться судинний чинник $[1,2]$.

Останніми роками зростає кількість АЗН, спричинених загальною патологією організму (атеросклероз, гіпертонічна та гіпотонічна хвороби, цукровий діабет, авітаміноз) [8]. АЗН при гіпертонічній хворобі $\epsilon$ наслідком гіпертонічної нейроретинопатії. Також порушується живлення нервових волокон на фоні патології кровоносних судин, пов'язане з гіпертонією. В літературі описані випадки АЗН, спричинені облітеруючим ендартеріїтом, вузликовим периартеріїтом, хворобою Такаясу, хворобою Рейно, тромбозом внутрішньої сонної артерії, постпрофузними внутрішніми кровотечами різної етіології [9].

На сьогодні не існує єдиної, загальноприйнятої класифікації атрофії зорового нерва, яка б враховувала всі чинники етіології, патогенезу та клінічної картини хвороби. Також проблемними залишаються діагностика та лікування цієї патології. Розробка нових доступних методів діагностики, а також патогенетичного лікування атрофії зорового нерва $є$ актуальним завданням сучасної офтальмології.

Мета дослідження - проведення аналізу етіології і частоти атрофії зорового нерва судинного генезу.

Матеріали і методи. Під нашим спостереженням знаходилося 38 пацієнтів (38 очей) з передньою іше- 
мічною оптичною нейропатією. Чоловіків було 15 $(39,5 \%)$, жінок - 23 (60,5\%) особи. Вік пацієнтів склав 27-84 роки (в середньому 61,6 року). Середній показник перебування в лікарні становив 9,89 ліжкодня.

Усім пацієнтам проводилося в динаміці: візометрія, периметрія, пневмотонометрія, біомікроскопія, офтальмоскопія, гоніоскопія, фосфендіагностика.

Статистичну обробку отриманих даних проводили в авторському пакеті Med Stat [Лях Ю.С., Гур'янов В.Г., 2004-2012 pp.] і статистичному пакеті EZR v. 1.35 [Saitama Medical Center, Jichi Medical University, Saitama, Японія, 2017].

Термін спостереження - 2013-2017 роки.

Результати та їх обговорення. У чотирьох хворих після розвитку ПІОН на одному оці через певний проміжок часу було діагностовано ішемічну нейропатію іншого ока. У двох випадках цей проміжок становив один місяць, у третьому випадку - 10 місяців, а в четвертому -8 місяців. Так, в період від 1 до 5 років після судинної катастрофи в оці у $34 \%$ хворих відбулися інші судинні порушення - ішемічна нейропатія іншого ока, інфаркт міокарда, гостре порушення мозкового кровообігу, облітеруючий ендартеріїт, тромбофлебіт нижніх кінцівок. Таким чином, судинні ураження зорового нерва є лише одним із проявів загальної судинної патології організму.

Період 3 моменту появи перших симптомів хвороби і звернення хворих за медичною допомогою був досить значним і становив у середньому 10,08 доби. За нашими даними, причинами передньої ішемічної нейропатії були гіпертонічна хвороба, цукровий діабет та атеросклероз (табл. 1). В одному з випадків причину розвитку судинної катастрофи в оці не було встановлено.

3 метою визначення наслідків ішемічної нейропатії проводилося повторне амбулаторне обстеження 19 хворих (23 ока) з діагнозом ПІОН для визначення функціонального стану зорового аналізатора. Період 3 моменту постановки діагнозу передньої ішемічної нейрооптикопатії до повторного дослідження тривав від одного до чотирьох років (в середньому - 2,17 року).

У всіх хворих при проведенні прямої офтальмоскопії спотерігали на очному дні різної інтенсивності побліднення диска зорового нерва, межі якого в більшості випадків були чіткими, помічали зменшення кількості дрібних судин, котрі проходять через край диска (позитивний симптом Кестенбаума). Така картина очного дна характерна для атрофії зорового нерва.

В якості порівняння, при проведенні клінічного обстеження 3 подальшим кореляційним аналізом отриманих даних, використовували дані гостроти зору, сумарних меж поля зору та порога електричної чутливості зорового нерва по фосфену на момент виписки з лікарні.

Таким чином, у результаті клінічного дослідження було встановлено достовірне зниження середнього показника гостроти зору з $0,22 \pm 0,06$ до $0,14 \pm 0,05$, звуження сумарних меж поля зору (СГПЗ) з 204,3 $\pm 22,7$ до $199,1 \pm 30,2$, підвищення порога електричної чут-

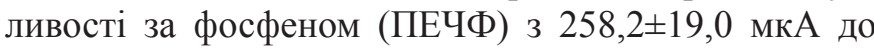
$295,8 \pm 26,5$ мкА.

Порівняльну оцінку змін показників гостроти зору, сумарних меж поля зору та порога електричної чутливості за фосфеном представлено в табл. 2.

Отже, в результаті дослідження встановлено, що у віддаленому періоді (1-4 роки) у всіх клінічних випадках після перенесеної ПІОН спостерігалася часткова атрофія зорового нерва 3 достовірним зниженням функціональних показників відносно раннього періоду хвороби. Для встановлення ступеня тяжкості патологічного процесу використали запропоновану нами класифікацію часткової атрофії зорового нерва.

Розподіл очей (19 хворих, 23 ока) в залежності від ступеня часткової атрофії зорового нерва наведено на рисунку.

Отримані результати свідчать, що майже у половини клінічних випадків $(47,83 \%)$ розвинулась атрофія зорового нерва IV ступеня, у 13,04\% було діагностовано V ступінь АЗН, коли зміни в зоровому нерві мають незворотній характер і відповідно низькі зорові функції, що свідчить про інвалідизацію даної групи пацієнтів.

Таким чином, отримані дані вказують на тяжкість наслідків такого захворювання, як передня ішемічна оптична нейропатія, а також необхідність повторної диспансеризації хворих з метою профілактики розвитку атрофії зорового нерва.

Характеристика причин передньої ішемічної оптичної нейропатії

\begin{tabular}{|c|c|c|c|c|c|c|}
\hline \multirow{2}{*}{ Етіологічний фактор } & \multicolumn{2}{|c|}{ Чоловіки } & \multicolumn{2}{|c|}{ Жінки } & \multicolumn{2}{|c|}{ Разом } \\
\hline & Абс. число & $\%$ & Абс. число & $\%$ & Абс. число & $\%$ \\
\hline гіпертонічна хвороба & 10 & 66,6 & 15 & 65,2 & 25 & 65,8 \\
\hline цукровий діабет & 1 & 6,6 & 4 & 17,4 & 5 & 13,1 \\
\hline атеросклероз & 3 & 20,2 & 4 & 17,4 & 7 & 18,4 \\
\hline не визначений & 1 & 6,6 & 0 & 0 & 1 & 2,7 \\
\hline Разом & 15 & 100 & 23 & 100 & 38 & 100 \\
\hline
\end{tabular}


Характеристика динаміки гостроти зору, СГПЗ та ПЕЧФ

Табличя 2

\begin{tabular}{|c|c|c|c|c|c|}
\hline \multirow{2}{*}{ Клінічні параметри } & \multirow{2}{*}{ Період спостереження } & \multicolumn{4}{|c|}{ Основні статистичні показники } \\
\hline & & $M$ & $S D$ & $m$ & $p$ \\
\hline \multirow{2}{*}{ гострота зору } & на момент виписки з лікарні & 0,22 & 0,22 & 0,06 & \\
\hline & на момент огляду & 0,14 & 0,27 & 0,05 & $<0,001$ \\
\hline \multirow{2}{*}{$\begin{array}{c}\text { СГПЗ, } \\
\text { град. }\end{array}$} & на момент виписки з лікарні & 204,3 & 140,0 & 22,7 & \\
\hline & на момент огляду & 199,1 & 145,0 & 30,2 & $<0,05$ \\
\hline \multirow{2}{*}{$\begin{array}{c}\text { ПЕЧФ, } \\
\text { мКА }\end{array}$} & на момент виписки з лікарні & 258,2 & 117,3 & 19,0 & \\
\hline & на момент огляду & 295,8 & 127,3 & 26,5 & $<0,05$ \\
\hline
\end{tabular}

Примітки:

M - середнє арифметичне значення результатів вимірювань;

$\mathrm{SD}$ - середнє квадратичне відхилення однієї величини;

$\mathrm{m}$ - середнє квадратичне відхилення середнього арифметичного значення;

p - ступінь достовірності різниць показників

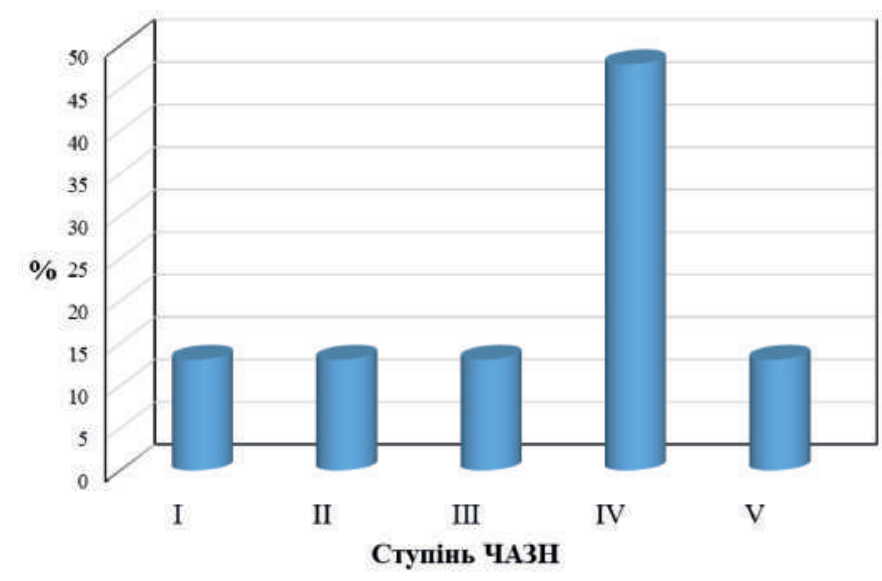

Рuc. Розподіл хворих за ступенем часткової атрофії зорового нерва

\section{Висновки}

Частота розвитку АЗН у пацієнтів після перенесеної ПІОН у віддаленому періоді (1-4 роки) складає 100\%.

Основними етіологічними факторами розвитку ПІОН є загальна судинна патологія організму та судинна патологія зорового нерва.

Передня ішемічна оптична нейропатія $\epsilon$ однією 3 важливих причин розвитку атрофії зорового нерва.

Відсутність критеріїв оцінки тяжкості патологічного процесу робить неможливим верифікацію ступеня часткової атрофії зорового нерва.

\section{Література}

1. Васюта В. А. Неврологічні аспекти атрофій зорових нервів / В. А. Васюта // Міжнародний неврологічний журнал. - 2015. - № 2. - С. 67-69.

2. Васюта В. А. Комплексний аналіз етіологічних чинників розвитку атрофії зорових нервів / В. А. Васюта // Буковинський медичний вісник. - 2015. - T. 19, № 2 (74). - C. 31-34.

3. Жабоєдов Г. Д. Нові можливості лікування часткових атрофій зорових нервів / Г. Д. Жабоєдов,
Р. Л. Скрипник, В. А. Васюта // Український неврологічний журнал. - 2007. - № 2. - С. 18-21.

4. Касымова М. С. Реабилитация больных с ишемическими нейропатиями зрительного нерва / М. С. Касымова // Вестник восстановительной медицины. - 2009. - № 3. - С. 84-86.

5. Киселева T. Н. Глазной ишемический синдром (клиника, диагностика, лечение): автореф. дис. ... д-ра. мед. наук / Т. Н. Киселева. - М., 2001. - 32с.

6. Мирошникова Л. М. Клиника и лечение острых сосудистых оптических нейропатий. / Л. М. Мирошникова, В. С. Дроздовская, Л. Г. Смидович, Аль-Захер Сами Мутанос // Офтальмологический журнал. - 1989. - № 6. - С. 374-376.

7. Петренко А. Ю. Стволовые клетки. Свойства и перспективы клинического применения / А. Ю. Петренко, Ю. А. Хунов, Э. Н. Иванов. - Луганск: Пресс-Экспресс, 2011. - 368 с.

8. Скрипник Р. Л. Пошкодження зорового нерва при цукровому діабеті (патогенез, клініка, діагностика, лікування): автореф. дис. на здобуття наук ступеня д-ра мед. наук: спец. 14.01.18 «Офтальмологія» / Р. Л. Скрипник. - Київ, 2005. - 45 с.

9. Chinnery P. F. Mitochondrial genetics / P. F. Chinnery, G. Hudson // Br. Med. Bull. - 2013. - Vol. 106. - P. 135-159.

10. Hoffmann J. Volumetric assessment of optic nerve sheath and hypophysis in idiopathic intracranial hypertension / J. Hoffmann, C. Schmidt, H. Kunte [et al.] // Am. J. Neuroradiol. - 2014. - Vol. 35. - P. 513-518.

11. Mizener J. B. Ocular ischemic syndrome. / J. B. Mizener, P. Podhajsky, S. S. Hayreh // Ophthalmology. - 1997. - Vol. 104. - P. 859-864.

12. Wall M. Risk factors for poor visual outcome in patients with idiopathic intracranial hypertension / M. Wall, J. Falardeau, W. A. Fletcher [et al.] // Neurology. - 2015. - Vol. 85. - P. 799-805. 


\title{
К ВОПРОСУ ЭТИОЛОГИИ И ЧАСТОТЫ АТРОФИИ ЗРИТЕЛЬНОГО НЕРВА СОСУДИСТОГО ГЕНЕЗА
}

\section{И. В. Галинская}

Заболевания зрительного нерва являются основной причиной слабовидения и слепоты. Согласно данным литературы, среди этиологических факторов атрофии зрительного нерва (АЗН), не связанных с заболеваниями ЦНС, первое место занимает сосудистый фактор. В структуре причин атрофии зрительного нерва сосудистой этиологии первое место принадлежит передней ишемической оптической нейропати (ПИОН). Целью исследования стало проведение анализа этиологии и частоты атрофии зрительного нерва сосудистого генеза. Под нашим наблюдением находились 38 пациентов (38 глаз) с передней ишемической оптической нейропатией. Мужчин было 15 (39,5\%), женщин - 23 (60,5\%). Возраст пациентов составлял 27-84 года (в среднем 61,6 года). Основными этиологическими факторами ПИОН являются общая сосудистая патология организма и сосудистая патология зрительного нерва. Частота развития АЗН в отдаленном периоде (1-4 года) после перенесенной ПИОН составляет $100 \%$.

Ключевые слова: сосудистые нарушения, передняя ишемическая оптическая нейропатия, атрофия зрительного нерва.

\section{ISSUE OF ETIOILOGY AND FREQUENCY OF ATROPHY OF THE OPTIC NERVE OF THE VASCULAR GENESIS}

\author{
I. V. Galinska \\ Vinnytsa National Medical University named after M. I. Pirogov of the Ministry of Public Health of Ukraine \\ Vinnitsa, Ukraine
}

Introduction. Diseases of the optic nerve are the main cause of weakness and blindness. According to the literature, among the etiological factors of atrophy of the optic nerve (AON), not related to diseases of central nervous system, the first place belongs to the vascular factor. In the structure of the causes of optic nerve atrophy of the vascular genesis, anterior ischemic optic neuropathy (AION) ranks first.

The aim of the study. To analyze the etiology and frequency of atrophy of the optic nerve of the vascular genesis.

Material and methods. We observed 38 patients (38 eyes) with anterior ischemic optic neuropathy. The observation included 15 men (39.5\%) and 23 women (60.5\%). The age of patients was $27-84$ years (average 61.6 years). Observation period: $2013-2017$ years.

Results and discussion. In four patients, after the development of AION in one eye, an ischemic neuropathy of the other eye was diagnosed within a certain period of time. In two cases, this period was one month, in the third case -10 months, and in the fourth -8 months. The main etiological factors of AION are general vascular pathology of the body and vascular pathology of the optic nerve.

In order to determine the effects of ischemic neuropathy, a recurrent outpatient examination of 19 patients ( 23 eyes) with a diagnosis of AION was performed to determine the functional state of the visual analyzer. The period from the diagnosis of anterior ischemic neuropathy to a re-examination was from one to four years (on average $-2,17$ years).

All patients with direct ophthalmoscopy were observed at the ocular fundus of varying intensity of paleness of the optic nerve disc.

Thus, as a result of the clinical study, a significant reduction in the mean visual acuity index was established with $0.22 \pm 0.06$ to $0.14 \pm 0.05$, the narrowing of the boundary of the field of view was from $204.3 \pm 22.7^{\circ}$ to $199.1 \pm 30.2^{\circ}$, increasing the threshold of electrical sensitivity to phosphene with $258.2 \pm 19.0 \mu \mathrm{A}$ to $295.8 \pm 26.5 \mu \mathrm{A}$.

Conclusions. The frequency of the AON in the remote period (1-4 years) after the suffered AION is $100 \%$. The main etiological factors in the development of AION are general vascular pathology of the body and vascular pathology of the optic nerve. Anterior ischemic optic neuropathy is one of the important causes of the development of optic nerve atrophy. Deficiency of criteria for assessing the severity of the pathological process makes it impossible to verify the degree of partial optic nerve atrophy.

Key words: vascular disorders, anterior ischemic optic neuropathy, optic nerve atrophy.

Стаття надійшла до редакції 28.06.2018 p. 